\title{
A METAMORFOSE DAS IDEIAS: OS SENTIDOS DAS IMPRESSÕES EM HUME
}

\author{
Guilherme Müller Junior ${ }^{1}$ \\ Universidade Estadual do Norte do Paraná (UENP) \\ (iD) https://orcid.org/0000-0002-7644-6450
}

\section{RESUMO:}

O cerne da problemática empirista de Hume está na questão do estatuto da experiência. Esse conceito se desdobra, em sua filosofia, nas distinções que ele faz entre as diferentes impressões, entre os diferentes processos originários de ideias. Sejam elas simples ou complexas, de sensação ou de reflexão, cada impressão produz uma determinada ideia. Cada impressão, portanto, corresponde a um processo específico de produção das ideias. $O$ presente artigo tem como propósito investigar o estatuto das impressões em Hume, bem como o processo de surgimento e de transformação das ideias. Acreditamos, pelas razões que aqui procuramos expor, que a experiência em Hume funciona como uma metamorfose, pois ela é a transmutação de um único e mesmo material. Trata-se de um percurso, de um devir que vai do simples ao complexo, das sensações à reflexão, por pura imanência.

PALAVRAS-CHAVE: Percepção; Impressão; Experiência; Ideia; Hume.

\section{THE METAMORPHOSIS OF IDEAS: THE SENSES OF IMPRESSIONS IN HUME}

\begin{abstract}
:
The core of Hume's empiricist problematic is the question of the status of experience. This concept unfolds, in his philosophy, in the distinctions he makes between the different impressions, between the different originating processes of ideas. Whether they are simple or complex, of sensation or reflection, each impression produces a certain idea. Each impression, therefore, corresponds to a specific process of producing ideas. This article aims to investigate the status of impressions in Hume, as well as the process of emergence and transformation of ideas. We believe, for the reasons we were seek here, that the experience in Hume functions as a metamorphosis, for it is the transmutation of one and the same material. It is a journey; it is a becoming that goes from the simple to the complex, from the sensations to the reflection, by pure immanence.
\end{abstract}

KEYWORDS: Perception; Impression; Experience; Idea; Hume.

\footnotetext{
${ }^{1}$ Doutor em Filosofia pela Universidade Federal do Rio de Janeiro (UFRJ), Rio de Janeiro - Brasil. Professor da Universidade Estadual do Norte do Paraná (UENP), Paraná - Brasil. E-mail: guilhermemuller@uenp.edu.br.
}

JUNIOR, Guilherme Müller. A metamorfose das ideias: os sentidos das impressões em Hume. Griot : Revista de Filosofia, Amargosa, Bahia, v.16, n.2, p.253-269, dezembro/2017. 


\section{Introdução}

O presente artigo tem como principal questão o estatuto das impressões na filosofia empirista de Hume. Logo nas primeiras Seções do seu Tratado da Natureza Humana Hume divide as percepções em duas: impressões e ideias (Cf. 2009, p. 25) ${ }^{2}$. Logo em seguida ele faz uma segunda divisão das percepções, em simples e complexas. Simples são as percepções, impressões ou ideias, que não admitem separação, pois são átomos. Complexas são as percepções compostas, são agregados ou relações de percepções simples. Mais adiante Hume subdivide as impressões em impressões de sensação e de reflexão (Cf. TNH, p. 32). Contudo, ele não deixa claro qual dessas impressões é simples e qual é complexa, ou se ambas podem ser simples e complexas. Trata-se de quatro tipos de impressões distintas ou de apenas duas? Qual o sentido dessas divisões? Eis as questões que gostaríamos de responder aqui.

Em um primeiro momento trataremos das distinções entre as impressões e ideias, sejam elas simples ou complexas. Quais seus respectivos processos? Em seguida nos debruçaremos sobre as impressões de sensação e de reflexão, com o objetivo de investigar se a simplicidade e a complexidade das percepções, sejam elas impressões ou ideias, se aplicam a ambos os tipos de impressões.

Seguiremos a perspectiva aberta por Deleuze, sobre a diferença entre as impressões e as ideias em Hume: "A diferença não se encontra, pois entre ideias $e$ impressões, mas entre duas espécies de impressões e ideias, as impressões ou ideia de termos $e$ as impressões ou ideias de relações" (DELEUZE, 2006, p. 212). Ou seja, o mais importante da filosofia de Hume não se encontra na diferença, por ele marcada, entre as impressões e as ideias, mas entre dois tipos de processos, entre duas experiências distintas: impressões de termos ou átomos (simples) e impressões de relação ou associação (complexas). Qual é qual? Qual é a de sensação e qual é a de reflexão? São ambas? Ambas fornecem simplicidade e complexidade? Acreditamos que não, pelas razões que aqui gostaríamos de expor. O cerne da nossa investigação, nesse sentido, concentra-se precisamente naquilo que se passa com as ideias, em ambas as impressões. Conforme a pista aberta por Deleuze não são as mesmas ideias, uma vez que não são as mesmas impressões. Respondendo a essas questões acreditamos, inclusive, que nos instalaremos no âmago do empirismo de Hume, que mora exatamente no problema da experiência.

\section{Impressões e ideias}

Hume, aparentemente, inicia sua filosofia como um empirista clássico, tratando do problema da origem das ideias. Nesse ponto, ele não é tão original, pois parece somente inverter a relação sujeito-objeto do racionalismo, e repetir uma já conhecida crítica ao inatismo. Para tanto, ele distingue duas espécies de percepções da mente:

As percepções da mente humana se reduzem a dois gêneros distintos, que chamarei de IMPRESSÕES e IDEIAS. A diferença entre estas consiste nos graus de força e vividez com que atingem a mente e penetram em

${ }^{2}$ Para as próximas citações do Tratado da Natureza Humana usaremos TNH. 
nosso pensamento ou consciência. As percepções que entram com mais força e violência podem ser chamadas de impressões; sob esse termo incluo todas as nossas sensações, paixões e emoções, em sua primeira aparição à alma. Denomino ideias as pálidas imagens dessas impressões no pensamento e no raciocínio, como, por exemplo, todas as percepções despertadas pelo presente discurso, excetuando-se apenas as que derivam da visão e do tato, e excetuando-se igualmente o prazer ou o desprazer imediatos que esse mesmo discurso possa ocasionar. Creio que não serão necessárias muitas palavras para explicar essa distinção. (HUME, 2009, p. 25)

Parece não haver nada de diferente ou especial em tais distinções, pelo menos em uma rápida leitura. Tratar-se-ia da tese acerca da origem das ideias, a fórmula do empirismo em geral. Parece que Hume, ainda aqui, é um herdeiro legítimo do empirismo clássico. Admite, inclusive, que esse princípio da anterioridade das impressões às ideias, da origem das ideias nas impressões, é o mesmo desenvolvido por aqueles que combateram as ideias inatas (Cf. TNH, p. 31). Avançaremos com Hume nessas distinções preliminares para ver até onde ele nos leva. Ainda sobre as impressões e ideias ele observa:

Convém observar ainda uma segunda divisão entre nossas percepções, que se aplica tanto às impressões como às ideias. Trata-se da divisão em SIMPLES e COMPLEXAS. Percepções simples, sejam elas impressões ou ideias, são aquelas que não admitem nenhuma distinção ou separação. As complexas são o contrário dessas, e podem ser distinguidas em partes. (TNH, p. 26)

Sendo coerentes com o texto de Hume, não podemos deixar de concluir que as ideias complexas são compostas pelas ideias simples ${ }^{3}$. As complexas, por serem distinguíveis em partes, só podem ser compostas pelas simples. As partes das quais nos fala o texto, portanto, são as impressões ou ideias simples. Essas ideias simples são unidades indivisíveis: átomos. Logo, as ideias e impressões complexas nada mais são que relações entre essas unidades indivisíveis que são as ideias e impressões simples. Sabemos que as ideias simples derivam de impressões simples, pois elas se correspondem por um distanciamento de grau e vivacidade, pois guardam entre si apenas uma diferença de grau. É o que deveria acontecer entre as impressões e ideias em geral:

\footnotetext{
A primeira circunstância que me chama a atenção é a grande semelhança entre nossas impressões e ideias em todos os pontos, exceto em seus graus de força e vividez. As ideias parecem ser de alguma forma os reflexos das impressões; de modo que todas as percepções da mente são duplas, aparecendo como impressões e como ideias. (TNH, p. 26)
}

Essa é uma consequência direta da origem das ideias nas impressões. Das impressões às ideias, em geral, deve haver apenas uma diminuição de força e vividez. As ideias são perfeitas imagens das impressões. Contudo, Hume observa que as ideias complexas, muitas delas, não encontram impressões complexas que lhe

\footnotetext{
${ }^{3}$ Apenas antecipamos uma conclusão que é do próprio Hume. (Cf. TNH, p. 28)
} 
correspondam perfeitamente, do modo como acontece entre as impressões e ideias simples. Isso deveria contrariar a tese de que todas as nossas ideias derivam de impressões que lhes correspondam. Contudo, é aqui que sua filosofia começa a se singularizar, pois parece que as impressões complexas, mesmo sendo compostas por impressões e ideias simples, resultam de processos distintos que diferenciam sua natureza. Hume se vê obrigado a fazer algumas ressalvas. É o início de um movimento sutil que muda toda a sua problemática. É necessário transcrever aqui o seu texto:

Ao proceder a um exame mais rigoroso, vejo que me deixei levar longe
demais pelas primeiras aparências, e que terei de fazer uso da distinção das
percepções em simples e complexas para limitar a conclusão geral de que
todas as nossas ideias e impressões são semelhantes. Observo que muitas de
nossas ideias complexas jamais tiveram impressões que lhe
correspondessem, e que muitas de nossas impressões complexas nunca são
copiadas de maneira exata como ideias. Posso imaginar uma cidade como
a Nova Jerusalém, pavimentada de ouro e com seus muros cobertos de
rubis, mesmo que nunca tenha visto nenhuma cidade assim. Eu vi Paris;
mas afirmarei por isso que sou capaz de formar daquela cidade uma ideia
que represente perfeitamente todas as suas ruas e casas, em suas
proporções reais e corretas? (TNH, p. 27 )

Hume chegará à conclusão que marca o início do seu desvio de sua tese inicial, segundo a qual todas as ideias são cópias exatas de suas impressões. Parece haver diferença de natureza entre as ideias simples e complexas, pois ambas aparentam ter origens e processos distintos. Impressões simples e ideias simples se correspondem e guardam entre si mera diferença de grau, isso é certo ${ }^{4}$. Todavia, como lemos na citação anterior, as ideias complexas não parecem corresponder nem derivar diretamente de impressões complexas (Nova Jerusalém), assim como estas não parecem gerar ideias que lhes sejam cópias perfeitas (Paris). Obviamente isso só pode indicar que ambas as impressões, simples e complexas, não se dão da mesma maneira, já que não geram o mesmo tipo de ideias. Haveria, portanto, dois processos, duas espécies de impressões diferentes, já que há duas espécies de ideias distintas. E tal distinção não é de grau, mas de natureza, pois é bem verdade que entre as impressões simples e suas ideias há apenas diferença de grau, já que guardam entre si uma semelhança e correspondência, mas o mesmo não se pode exigir nem se esperar das impressões complexas e suas ideias. Entre a simplicidade e a complexidade das impressões e suas respectivas ideias há muito mais do que uma diferença de grau, há uma profunda diferença de natureza entre ambas as impressões, e consequentemente entre suas ideias. Eis o desvio. Nesse ponto Hume é explícito:

Percebo, portanto, que, embora haja em geral uma grande semelhança entre nossas impressões e ideias complexas, não é uma regra universalmente verdadeira que elas sejam cópias exatas uma das outras. Consideremos agora o que ocorre com nossas percepções simples. Após o

\footnotetext{
4 “Impressões e ideias diferem apenas em sua força e vividez". (TNH, p. 43). No caso das impressões e ideias complexas, isso também é verdade, mas de modo diferente do que ocorre entre as impressões e ideias simples, como se verá. Não há diferença de natureza entre uma impressão e a sua ideia, seja qual for, mas entre dois tipos de impressões e ideias (simples e complexas).
} 
exame mais rigoroso de que sou capaz, arrisco-me a afirmar que, aqui, a regra não comporta exceção, e que toda ideia simples tem uma impressão simples que a ela se assemelha; e toda impressão simples, uma ideia correspondente. A ideia de vermelho que formamos no escuro e a impressão que atinge nossos olhos à luz do sol diferem somente em grau, não em natureza. (TNH, p. 27)

Está aí salientada a diferença de natureza entre as impressões e ideias, complexas e simples. Todavia, como pretendemos aqui mostrar, não se trata apenas de uma exceção, mas de um elemento constitutivo da dinâmica das ideias. Não são as mesmas impressões e não são as mesmas ideias, não obstante serem feitos do mesmo material: as ideias complexas são compostas pelas ideias simples. Há, portanto, uma certa continuidade, uma linha que vai das impressões e ideias simples às impressões e ideias complexas. Mas é exatamente nessa linha contínua que algo acontece, pois é nas ideias complexas que a natureza das ideias muda. Não é o mesmo processo, não pode ser o mesmo processo. Impressões simples resultam em ideias simples perfeitamente correspondentes, pois ambas se assemelham, diferindo-se apenas por uma mera diminuição do grau de vivacidade. As ideias complexas se formam a partir das simples, mas as impressões que as geram não se dão da mesma forma, pelo mesmo processo, das que geram as ideias simples. Como visto, não há exata correspondência, já que pode haver defasagem em alguns casos e excessos em outros: Paris e Nova Jerusalém, respectivamente. Das ideias simples às complexas há uma continuidade do material, já que as complexas são compostas por partes, isto é, por ideias simples. Só assim, podemos entender a seguinte assertiva de Hume: "Vemos, assim, que todas as ideias e impressões simples se assemelham umas às outras. E, como as complexas se formam a partir delas, podemos afirmar de um modo geral que essas duas espécies de percepções são exatamente correspondentes" (TNH, p. 28). Considerando tudo o que Hume já nos falou sobre a diferença entre as percepções simples e complexas, essa correspondência só pode ser entendida quanto ao material que compõe as ideias complexas, mas não quanto ao seu respectivo processo de composição, quanto à experiência.

\section{Impressões de sensação e de reflexão}

Hume é coerente e fiel à tese da origem das ideias nas impressões. Mas não se trata da mesma tese do empirismo clássico, uma vez em que ele distingue dois processos, duas experiências. $O$ que ele nos revela, ao cuidar da distinção entre as ideias simples e complexas, é a diferença no processo de surgimento de ambas. Essas duas ideias sempre serão derivadas de impressões que lhes correspondam, mas a defasagem ou o excesso dos quais falamos a respeito das ideias complexas, nos mostram uma diferença de natureza entre as impressões simples e complexas. As ideias simples dependem das impressões simples, elas são o mesmo que suas impressões, apenas com uma diminuição de força. Essa é a correspondência e semelhança, já que as ideias simples são imagens menos vivazes das impressões simples. As ideias complexas também dependem das impressões complexas, pois delas derivam, porém de outro modo, em virtude do excesso ou da defasagem na qual resultam. Trata-se de outro tipo de imagem, pois se trata de outro tipo de

JUNIOR, Guilherme Müller. A metamorfose das ideias: os sentidos das impressões em Hume. Griot : Revista de 
experiência. Diremos então que entre as impressões e ideias simples há uma mera diferença de grau, uma diminuição da vivacidade, enquanto que entre as impressões e ideias complexas há uma diferença marcada por defasagens ou excessos. Mas, enfim, o que fazem as impressões complexas? O que são essas composições e relações das ideias simples, que Hume chama de ideias complexas? Por uma exigência lógica, as impressões complexas só podem ocorrer após as impressões simples, já que as ideias complexas são composições de ideias simples. É preciso que haja ideias simples, portanto, para que as impressões complexas produzam tais composições, ou seja, as ideias complexas. Todavia, o que ainda não está claro aqui é o modo de funcionamento de cada uma dessas impressões, os processos de onde emerge cada tipo de ideia, de imagens. A simplicidade das ideias, como partes mínimas e indivisíveis, são transformadas pelas impressões complexas. As ideias simples se prolongam nas ideias complexas, através do processo das impressões complexas. Esse prolongamento define a natureza das impressões complexas. É um prolongamento que muda tudo, pois transforma a natureza das ideias simples. Trata-se de um uso diferencial das ideias simples, por excesso ou defasagem. Hume sente, nesse ponto, a necessidade de conceituar essas duas modalidades de impressões qualitativamente, como dois processos produtivos distintos:

\begin{abstract}
As impressões podem ser divididas em duas espécies: de SENSAÇÃ̃ e de REFLEXÃO. As da primeira espécie nascem originalmente na alma, de causas desconhecidas. As da segunda derivam em grande medida de nossas ideias, conforme a ordem seguinte. Primeiramente, uma impressão atinge os sentidos, fazendo-nos perceber o calor ou o frio, a sede ou a fome, o prazer ou a dor, de um tipo ou de outro. Em seguida, a mente faz uma cópia dessa impressão, que permanece mesmo depois que a impressão desaparece, e à qual denominamos ideia. Essa ideia de prazer ou dor, ao retornar à alma, produz novas impressões, de desejo ou aversão, esperança ou medo, que podemos chamar propriamente de impressões de reflexão, porque derivadas dela. Essas impressões de reflexão são novamente copiadas pela memória e pela imaginação, convertendo-se em ideias - as quais, por sua vez, podem gerar impressões e ideias. Desse modo, as impressões de reflexão antecedem apenas suas ideias correspondentes, mas são posteriores às impressões de sensação, e delas derivadas. (TNH, p. 32)
\end{abstract}

Eis a linha contínua e diferencial do prolongamento das ideias simples nas complexas. Está tudo dito aí, pois nos parece que o Tratado inteiro é um desdobramento, uma explicação desse parágrafo. As impressões, conforme já nos disse Hume, são percepções primitivas do espírito, são aquelas que "entram com mais força e violência" (TNH, p. 25). Essas podem ser de dois tipos, segundo o que nos revela a citação acima: impressões de sensação e impressões de reflexão. De fato, Hume não é aí explícito, a ponto de dizer que se trata da mesma divisão anteriormente tratada, que uma é a impressão simples e a outra, complexa. Porém, não estamos autorizados a ver em seu texto quatro impressões diferentes, na medida em que ele já nos advertiu sobre a existência de apenas duas impressões, conforme a "segunda divisão entre nossas percepções, que se aplica tanto às impressões como às ideias" (TNH, p. 26). Não há uma terceira divisão. Algumas razões nos levam a crer que se trata da mesma divisão.

JUNIOR, Guilherme Müller. A metamorfose das ideias: os sentidos das impressões em Hume. Griot : Revista de 
As impressões divididas em simples e complexas concernem quantitativamente às ideias, à natureza mesma das ideias que delas derivam, enquanto que a divisão entre impressões de sensação e de reflexão concernem qualitativamente ao processo, à experiência, à natureza das impressões mesmas. Impressões de sensação e de reflexão são conceitos que qualificam os processos das impressões enquanto tais, como operações e movimentos produtivos, na medida em que impressões simples e complexas determinam aqueles processos do ponto de vista das ideias produzidas. Sensação e reflexão são as qualidades, os modos das impressões, simples e complexo são medidas quantitativas dessas mesmas impressões. Em outras palavras: determinado processo (modo e qualidade) geraria as ideias simples (impressões simples), ao passo que o outro geraria as ideias complexas (impressões complexas). São duas impressões tão somente, cada uma duplamente determinada. É o que nos cabe aqui explicitar, já que Hume parte destas distinções e as toma como entendidas, sem dizer expressamente de que se trata das mesmas impressões. Contudo, é precisamente nessa sua sutileza que está sua singularidade, pois é aí que encontraremos um dos traços mais fortes do seu empirismo, o traço que o desvia definitivamente da tradição. Só se pode compreender isso nas imbricações da dinâmica descrita por Hume na última passagem citada, ou seja, nos processos produtivos das impressões.

Conforme as razões aqui já expostas, há um movimento quantitativo, no que concerne às ideias produzidas, do simples ao complexo (Cf. TNH, p. 28). É essa, em outras palavras, a divisão das impressões em simples e complexas. Mas tal movimento das impressões é qualitativamente determinado, ora pela sensação e ora pela reflexão. Ambas as impressões, consideradas como processos produtivos de ideias, só podem produzir ideias simples ou complexas, necessariamente. Quanto aos seus produtos, portanto, as impressões de sensação e de reflexão serão também impressões simples ou complexas. Resta verificar em qual qualidade produtiva tal ou qual ideia é produzida. Só assim entenderemos, a partir dos modos e das qualidades produtivas das impressões, o que se passa no movimento do simples ao complexo, o tal uso diferencial a que nos referimos.

Tudo indica que a passagem das impressões simples às complexas é também um percurso das impressões de sensação às impressões de reflexão. É um mesmo material que passa de um ao outro e sofre um percurso diferencial. Com efeito, Hume deixa claro que o movimento se inicia com as sensações: “(...) uma impressão atinge os sentidos (...)" (TNH, p. 32). Posteriormente, algo resta dessa impressão, algo permanece no espírito: a ideia. É a imagem retida de uma impressão sensível, “(...) que permanece, mesmo depois que a impressão desaparece (...)" (TNH, p. 32). Tal é o material primitivo e mais elementar do espírito que irá percorrer um longo caminho minuciosamente pensado ao longo do Tratado, uma espécie de aventura das ideias ${ }^{5}$. As impressões dos sentidos são primitivas, originais, e como tais, só podem produzir um material também primitivo e original. As primeiras ideias, portanto, são ideias das impressões de sensação. São imagens dessas primeiras impressões, semelhantes e perfeitamente correspondentes. Sendo coerentes com o sentido geral que Hume atribui às ideias simples, podemos dizer que essas também são primeiras, em relação

\footnotetext{
5 Uma aventura das ideias poderia ser, sem nenhum problema, o subtítulo do Tratado da natureza humana, ou mesmo um outro nome da filosofia empirista de Hume.
}

JUNIOR, Guilherme Müller. A metamorfose das ideias: os sentidos das impressões em Hume. Griot : Revista de 
às ideias complexas. Ideias simples, como aqui já dito, só podem derivar de impressões simples. Ora, do mesmo modo, ideias primeiras e primitivas só podem derivar de impressões primeiras e primitivas. Nada é anterior a uma impressão de sensação, assim como nada é anterior a uma impressão simples. Ambas dão origem a um material primitivo e simples, a uma espécie de mínimo do espírito que não admite nenhuma divisão ou distinção (TNH, p. 26). Concluímos disso que ambas constituem uma mesma impressão: as impressões de sensação são também impressões simples. A sensação só nos fornece simplicidade, ideias simples, não distinguíveis nem separáveis em si mesmas. É verdade que Hume só diz isso de modo indireto e implícito, já que não nos deixa entender de maneira diversa. Atentemos para algumas passagens do seu texto e à correlação que ele estabelece entre as impressões dos sentidos e as ideias simples:

\begin{abstract}
Consideremos agora o que ocorre com nossas percepções simples. Após o exame mais rigoroso de que sou capaz, arrisco-me a afirmar que, aqui, a regra não comporta exceção, e que toda ideia simples tem uma impressão simples que a ela se assemelha; e toda impressão simples, uma ideia correspondente. A ideia de vermelho que formamos no escuro e a impressão que atinge nossos olhos à luz do sol diferem somente em grau, não em natureza. É impossível provar, por uma enumeração exaustiva de todos os casos, que o mesmo se dá com todas as nossas impressões e ideias simples. (TNH, p. 27)
\end{abstract}

Notemos que Hume correlaciona as impressões simples e as impressões de sensação: “(...) a impressão que atinge nossos olhos (...)". Poder-se-ia objetar, dizendo que as sensações também podem nos fornecer ideias complexas, podendo ser também impressões complexas. Mas Hume afasta essa hipótese do seguinte modo: "Embora uma cor, sabor e aroma particulares sejam todos qualidades unidas desta maçã, é fácil perceber que elas não são a mesma coisa, sendo ao menos distinguíveis umas das outras" (TNH, p. 26) ${ }^{6}$. São separáveis e distinguíveis na maçã, não em si mesmas como partes dela. Ou seja, a impressão que produz a ideia de maçã pode ser separada em outras impressões e ideias que, em si mesmas, não admitem separação. Portanto, é a maçã uma ideia complexa derivada de uma impressão complexa, na medida em que une determinadas impressões dos sentidos, tais como cor, sabor e aroma. Se tais impressões são separáveis uma das outras é justamente porque não são dadas unidas em uma única impressão dos sentidos. Pois para estarem unidas, é necessário que essas impressões tenham sido dadas primeiramente separadas, do contrário não seria possível separá-las. Se há ideia simples - e é necessário que haja, uma vez que há ideia complexa - é porque houve impressão simples. Não há duas sensações, uma primeira, que fornece dados inseparáveis e indistinguíveis em si mesmos e outra, que as une em uma segunda sensação. Há, sim, duas espécies de impressões, uma simples originária dos sentidos e outra, complexa, derivada de um processo distinto das sensações. Há, portanto, duas experiências.

Não se perca de vista o início de todo o processo tão bem descrito por Hume: "Primeiramente, uma impressão atinge os sentidos (...)" (TNH, p. 32). As sensações são impressões simples e como tais, só fornecem ideias simples, fragmentos, átomos

${ }^{6}$ Para outro exemplo do mesmo tipo, Cf. TNH, p. 254.

JUNIOR, Guilherme Müller. A metamorfose das ideias: os sentidos das impressões em Hume. Griot : Revista de 
indivisíveis em si mesmos. Hume aqui é explícito: "Embora certas sensações possam estar unidas em determinado momento, nós rapidamente descobrimos que elas admitem separação, e podem se apresentar separadamente" (TNH, p. 94). Admitem separação, já que são dadas originariamente separadas por impressões simples. Se tais impressões e ideias aparecem unidas em algum momento em uma impressão complexa, isso só pode ocorrer em outro processo, que não o da sensação em si mesma ${ }^{7}$. Desse modo, sendo a maçã do exemplo uma impressão complexa, ela só pode advir de outro processo, distinto e posterior às impressões e ideias simples de cor, sabor e aroma. Essas impressões dos sentidos não admitem separação ou distinção em partes, na medida em que elas mesmas são as partes mínimas que compõem a impressão da maçã. De acordo com a regra estabelecida por Hume, uma impressão ou ideia complexa pode facilmente ser separada em outras ideias e impressões (cor, aroma, sabor, e outras). Não há, como ficou claro, duas sensações, uma simples e outra composta. Pode haver um composto de sensações, implicado em uma impressão complexa, mas, como tal, não pode ser dada tal qual uma sensação. Na verdade, o que há é um composto de ideias de sensação, ideias simples, que unidas, podem compor uma impressão complexa originária de ideias complexas. Essa união, esse composto, resulta de um processo totalmente distinto das sensações. Contudo, esse processo também precisa ser chamado de impressão, já que dele derivam ideias.

Tudo indica, portanto, que as impressões complexas não estão nas sensações, não podem ser dadas pelos sentidos. As relações e composições de impressões e ideias simples não seriam dadas pelas sensações. Sendo assim, há ideias e impressões que não são dadas pela sensibilidade, pela experiência sensível. A ideia complexa é um composto que muda a natureza das ideias simples, natureza essa singular. As impressões complexas, já se pode dizer, unem as ideias de sensação em um processo de prolongamento e diferenciação. Essas impressões, ao produzirem esses compostos, vão além daquilo que é dado pelos sentidos, já que as sensações só fornecem simplicidade, singularidade. É o que Hume fala, em relação aos sentidos: "Pois tudo

\footnotetext{
${ }^{7}$ Insistimos nessas distinções por serem elas fundamentais, pois nos revelam a verdadeira diferença de natureza entre as ideias simples e complexas. As sensações, as impressões de sensação, são o processo originário das ideias simples. Se a sensibilidade fornecesse impressões complexas, seria possível dizer, por exemplo, que as ideias de causa e efeito resultam de uma sensação, ou seja, que ambas estariam dadas simultaneamente em uma única impressão sensível. Como se sabe, Hume nega peremptoriamente essa hipótese. Falamos aqui de sua célebre crítica ao conceito de causalidade. Sabese que a conexão entre a causa e o efeito não é dada pela sensibilidade, pois depende da ocorrência do hábito. (Cf. TNH, pp. 98, 111, 115-118). Recorremos a essa sua posição para nela apoiarmos nossa assertiva, a de que as sensações só nos fornecem singularidades. É o que Hume nos diz: “Que nossos sentidos não oferecem suas impressões como imagens de alguma coisa distinta, ou seja, independente e externa, é evidente. Pois tudo que eles nos transmitem é uma percepção singular, e jamais nos dão a menor indicação de algo além dela. Uma percepção singular nunca poderia produzir a ideia de uma dupla existência, a não ser por meio de alguma inferência da razão ou da imaginação. Quando a mente dirige sua visão para além daquilo que lhe aparece imediatamente, suas conclusões jamais podem ser levadas à conta dos sentidos (grifo nosso). E certamente é isso que ela faz quando, partindo de uma percepção singular, infere uma dupla existência e supõe, entre essas existências, as relações de semelhança e causalidade". (TNH, p. 222). Portanto, as ideias complexas, justamente aquelas que ultrapassam as ideias simples, só podem ser dadas por outro processo totalmente distinto das sensações.
}

JUNIOR, Guilherme Müller. A metamorfose das ideias: os sentidos das impressões em Hume. Griot : Revista de Filosofia, Amargosa, Bahia, v.16, n.2, p.253-269, dezembro/2017. 
que eles nos transmitem é uma percepção singular, e jamais nos dão a menor indicação de algo além dela" (TNH, p. 222). Ainda nesse mesmo parágrafo citado, ele complementa: "Quando a mente dirige sua atenção para além daquilo que lhe aparece imediatamente, suas conclusões jamais podem ser levadas à conta dos sentidos". As impressões complexas, justamente por unirem aquilo que aparece originariamente separado nas sensações, vão além dessas singularidades. Em virtude disso, não podem ser atribuídas às impressões de sensação, que, como dito, só transmitem uma "percepção singular". Trata-se efetivamente de outro processo.

As impressões de sensação são também impressões simples. É esse o primeiro sentido da experiência do empirismo de Hume: experiência sensivel. Tal é o processo de emergência das ideias simples, átomos e singularidades, tão somente. Mas Hume nos fala de impressões complexas, de ideias complexas, que se distinguem da natureza das impressões e ideias simples, não obstante serem compostas por estas. Ficou claro que a sensibilidade só pode fornecer simplicidade. Nesse sentido, se há ideias complexas essas só podem resultar de outro processo. Haveria assim outra experiência, já que dela resultaria outro tipo de ideia. Ou seja, haveria duas experiências distintas por natureza, já que de uma para outra ocorre uma profunda mudança de natureza das ideias, uma verdadeira metamorfose de um mesmo material. Essa segunda experiência é o que ainda nos resta entender. As ideias complexas, como aqui visto, só podem ser dadas por excesso ou defasagem, com relação à sensibilidade e às ideias simples, isto é, dizem mais (excessos) ou menos (defasagem) daquilo que é dado pela sensibilidade. Se por um lado já se pode compreender o processo das impressões simples (impressões de sensação), ainda resta a compreensão do processo que torna possível a emergência das impressões complexas. Para tanto, precisamos retornar ao itinerário das impressões e ideias e ver o que realmente acontece com as sensações e suas ideias, nesse devir.

Primeiramente, uma sensação da qual resulta uma ideia, ou seja, uma imagem retida no espírito. Eis o espírito, lugar das ideias, das imagens, precisamente o plano onde elas irão se encontrar e se atravessar. $O$ espírito não é diferente desses encontros, dessas imagens que se atravessam, ao contrário, é por elas definido (Cf. DELEUZE, 2001, p. 13). O que se pode dizer, depois de uma sensação e de suas retenções? O que acontece? É preciso voltar ao belo parágrafo de Hume:

Em seguida, a mente faz uma cópia dessa impressão, que permanece
mesmo depois que a impressão desaparece, e à qual denominamos ideia.
Essa ideia de prazer ou de dor, ao retornar à alma, produz novas
impressões, de desejo ou aversão, esperança ou medo, que podemos
chamar propriamente de impressão de reflexão, porque derivadas dela.
Essas impressões de reflexão são novamente copiadas pela memória e pela
imaginação, convertendo-se em ideias - as quais, por sua vez, podem gerar
outras impressões e ideias. Desse modo, as impressões de reflexão
antecedem apenas suas ideias correspondentes, mas são posteriores às
impressões de sensação, e delas derivadas. (TNH, p. 32 )

Após as impressões de sensações seguem as impressões de reflexão. Entre um e o outro processo há correspondência e continuidade do material envolvido: ideias. Entretanto, algo de diferente acontece com as ideias de sensação: retornam à alma e produzem novas impressões. Para esse retorno das ideias na alma, Hume cria o

JUNIOR, Guilherme Müller. A metamorfose das ideias: os sentidos das impressões em Hume. Griot : Revista de 
conceito de impressão de reflexão. É nesse retorno na alma, nessa repetição das ideias, que tudo muda e se diferencia. Como se pode ver na passagem citada, as ideias não cessam de retornar, de ser copiadas e de se repetir no espírito, gerando sempre novas impressões e novas ideias. Todavia, não se trata de uma atividade do espírito, mas de um movimento que é próprio das ideias, das imagens: "E como as impressões de reflexão - a saber, as paixões, os desejos e as emoções, que sobretudo merecem nossa atenção - surgem em sua maior parte de ideias (...)" (TNH, p. 32). As impressões de reflexão consistem nesse retorno, nessa repetição das ideias no espírito. É um processo que prolonga as ideias, que resulta desse retorno e repetição de uma ideia. São as ideias simples das impressões de sensação, que se atravessam e se encontram, fazendo assim surgir outras espécies de impressões, e consequentemente outras ideias. Ora, o encontro de ideias simples só pode resultar em ideias complexas. Tal encontro, portanto, só pode ser a expressão de uma impressão complexa. Concluímos assim que as impressões de reflexão são impressões complexas. Eis o segundo sentido da experiência: impressões de reflexão. De fato, Hume não diz isso explicitamente. Mas novamente aqui não nos deixa entender de outra maneira. Ele nos fala sobre dois modos das ideias retornarem e se repetirem: "Essas impressões de reflexão são novamente copiadas pela memória e pela imaginação, convertendo-se em ideias - as quais, por sua vez, podem gerar outras impressões e ideias" (TNH, p. 32). Com relação às impressões de sensação, que são primitivas por natureza, essas outras impressões são derivadas, originárias apenas das ideias que produzem. Ou seja, já são repetições de um mesmo material fornecido pelas sensações. Continuando a última citação: "Desse modo, as impressões de reflexão antecedem apenas suas ideias correspondentes, mas são posteriores às impressões de sensação, e delas derivadas" (TNH, p. 32). Isso é evidente com relação às impressões complexas, já que estas necessitam da anterioridade das impressões e ideias simples para produzirem suas composições. Parece, portanto, que o funcionamento das impressões de reflexão só pode ser entendido pelos diferentes modos de repetição das ideias. A respeito dessa questão ele nos diz:

Pela experiência vemos que, quando uma determinada impressão esteve presente na mente, ela ali reaparece sob a forma de uma ideia, o que pode se dar de duas maneiras diferentes: ou ela retém, em sua nova aparição, um grau considerável de sua vividez original, constituindo-se em uma espécie de intermediário entre uma impressão e uma ideia; ou ela perde inteiramente aquela vividez, tornando-se uma perfeita ideia. A faculdade pela qual repetimos nossas impressões da primeira maneira se chama MEMÓRIA, e a outra, IMAGINAÇÃO. É evidente, mesmo à primeira vista, que as ideias da memória são muito mais vivas e fortes que as da imaginação, e que a primeira faculdade pinta seus objetos em cores mais distintas que todas as que possam ser usadas pela última. Ao nos lembrarmos de um acontecimento passado, sua ideia invade nossa mente com força, ao passo que, na imaginação, a percepção é fraca e lânguida, e apenas com muita dificuldade pode ser conservada firme e uniforme pela mente durante um período considerável de tempo. (TNH, p. 33)

A memória é uma espécie de intermediário entre uma ideia e sua respectiva impressão. A memória é uma ponte entre uma ideia qualquer e a impressão que lhe deu origem. As ideias da memória são ainda meras ideias, contudo são as mais

JUNIOR, Guilherme Müller. A metamorfose das ideias: os sentidos das impressões em Hume. Griot : Revista de 
vívidas, pois guardam em maior grau a ordem e a posição de suas ideias em relação as suas impressões. A memória, justamente por isso, está presa a essa ordem, a essa posição das ideias. Só as repete para reacender a posição das ideias e de suas respectivas impressões. $O$ verdadeiro problema está na liberdade da imaginação, ou seja, na perfeita ideia, já que ela não está presa a nada. Uma perfeita ideia, é o que Hume nos diz, e não uma ideia perfeita. Trata-se de uma ideia pura, solta, livre de qualquer ordem ou posição, com relação as suas impressões. É só aí que o problemático começa a aparecer, pois é na imaginação que as ideias podem qualquer coisa. Hume segue, marcando esse caráter da imaginação, contrastando-a com a memória:

Há uma outra diferença, não menos evidente, entre esses dois tipos de ideias. Embora nem as ideias da memória nem as da imaginação, nem as ideias vívidas nem fracas possam surgir na mente antes que impressões correspondentes tenham vindo abrir-lhes o caminho, a imaginação não se restringe à mesma ordem e forma das impressões originais, ao passo que a memória está de certa maneira amarrada quanto a esse aspecto, sem nenhum pode de variação. (TNH, p. 33)

Se as ideias da memória, por estarem amarradas as suas impressões originais, não desfrutam de poder de variação. As ideias da imaginação, ao contrário e justamente por serem ideias puras e soltas, usufruem de um poder absoluto de variação. É precisamente por isso, que o problema das impressões de reflexão e das ideias complexas está intimamente relacionado a esse poder da imaginação ${ }^{8}$. É na imaginação que as ideias se libertam de sua posição com relação às impressões, com relação a sua origem. É apenas na imaginação que as ideias podem flutuar livremente, precisamente onde tais imagens podem se encontrar e se atravessar em qualquer posição. No entanto, é acerca de um mesmo material que se está falando. As ideias simples são dadas pelas impressões simples, pelas impressões de sensação. Essas mesmas impressões podem ser retidas em um espírito como imagens (ideias), e são justamente essas imagens que constituirão o espírito como tal. Essas ideias podem retornar e serem repetidas no espírito, de duas maneiras distintas. A memória compromete as ideias, já que as amarra à força com que nasceram. Na imaginação as ideias perdem esse compromisso, perdem essa força e vivacidade conferidas pelas impressões e se tornam perfeitas ideias. As imagens e ideias só se tornam perfeitas e puras à custa desse esquecimento essencial que é a imaginação. Desse modo, é com a

\footnotetext{
8 Afirmamos que as ideias complexas só podem ser dadas pelas impressões de reflexão pelas razões aqui já expostas. Ao contrário do que acontece entre as impressões de sensação e as impressões simples (as impressões de sensação só podem fornecer ideias simples), é concebível que as impressões de reflexão possam produzir também ideias simples. É o que Hume nos deixa entender com o papel que ele atribui à memória. Uma ideia simples, indivisível e singular, pode ser remetida à impressão que lhe deu proveniência pela memória, assim como a ideia de gosto e a sua impressão no exemplo da maçã. Ora, isso seria uma impressão de reflexão. A memória, tudo indica, repete as ideias com relação às suas impressões. Ela mantém a vividez das ideias, tal como ela é dada pela sua impressão correspondente. É por isso que ela se relacionará com a crença tal qual um sentimento (Cf. TNH, p. 115). Mas a memória parece não relacionar as ideias, ela não tem o mesmo poder e a mesma liberdade da imaginação. É o que Hume nos mostra com essas definições da memória no início do Tratado. Quanto a sua função ele é aí bem claro: "A principal função da memória não é preservar as ideias simples, mas sua ordem e posição". (TNH, pp. 33-34)
}

JUNIOR, Guilherme Müller. A metamorfose das ideias: os sentidos das impressões em Hume. Griot : Revista de Filosofia, Amargosa, Bahia, v.16, n.2, p.253-269, dezembro/2017. 
perda de força e vivacidade das ideias que a imaginação, ou melhor, as ideias na imaginação, adquirem uma outra força e vivacidade: um poder absoluto de variação. Uma perfeita ideia, ou uma ideia pura, é também uma ideia neutra, já que não está comprometida com nenhuma origem. Só assim ela pode variar, prolongar e ser prolongada, repetir e ser repetida, se associar com outras ideias de forma livre. $A$ imaginação é um plano que neutraliza e inocenta as ideias. Bem se vê aí a linha contínua e diferencial das ideias. São as mesmas impressões e são as mesmas ideias, porém, não são mais as mesmas do ponto de vista de suas naturezas. É um mesmo material que não cessa de se transformar em uma contínua metamorfose. Só há um material, e um incessante devir experimental. A experiência sensível não é a única, pois suas ideias percorrerão um caminho aventureiro de outras experiências. Desde a sensação à reflexão é um único material que se transforma. Tudo indica que é na imaginação que esse devir se faz, já que ela parece funcionar como um solo ou um meio das ideias, das perfeitas ideias. É o que Hume nos autoriza a pensar. Ele nos diz:

\begin{abstract}
Nada é mais livre que a imaginação humana, e, embora não possa ir além daquele inventário original de ideias fornecidas pelos sentidos internos e externos, ela dispõe de poder ilimitado para misturar, combinar, separar e dividir essas ideias em todas as variedades de ficção e miragens. É-lhe possível inventar uma série de acontecimentos que têm toda a aparência de realidade, atribuir-lhes uma ocorrência em um local e momentos precisos, concebê-los como existentes e pintá-los para si mesma com todas as circunstâncias apropriadas a um fato histórico qualquer, no qual acredite com a máxima certeza. (HUME, 1999, p. 70)
\end{abstract}

Há, portanto, um mesmo material que se transforma em um incessante devir. A imaginação está limitada a esse material, já que ela não pode ir além dos dados fornecido pelas impressões, sejam elas de sensação ou de reflexão ("externo" e "interno"). Todavia, ela é livre para experimentar esses dados e repeti-los em novas impressões.

\title{
A experiência imanente: a metamorfose das ideias
}

Hume nos fala sobre o espírito, a mente e a imaginação. Essa divisão pode suscitar a questão de inerência de um ao outro. Entretanto, essa divisão é meramente aparente. A imaginação não pode ser entendida como um atributo inerente ao espírito, como uma faculdade pertencente a uma substância subjetiva imaterial. Quando Hume nos diz que ela é uma faculdade parece fazê-lo apenas por convenção, como um esforço para se fazer compreendido (Cf. TNH, p. 33). A imaginação é livre, e somente por essa absoluta liberdade pode ser ela compreendida. Não estaria ela submetida a um espírito, menos ainda à vontade ou a qualquer outra faculdade de um sujeito ${ }^{9}$. Não é a atividade de algo, mas um movimento livre próprio das ideias. Ademais, as próprias percepções não são concebidas como inerentes a algo delas

\footnotetext{
${ }^{9} \mathrm{O}$ sujeito ainda não apareceu. Nada do que foi dito aqui pressupõe a existência e a atividade de uma subjetividade. O espírito, ou a mente, não pode em hipótese nenhuma ser confundido com uma substância subjetiva imaterial em Hume (Cf. TNH, Livro 1, Parte 4, Seção 5 e 6).
} 
diferentes, seja uma substância material ou imaterial. $O$ próprio Hume escreve de forma clara:

\begin{abstract}
Assim, nem considerando a origem das ideias, nem por meio de uma definição somos capazes de chegar a uma noção satisfatória de substância. Isso me parece uma razão suficiente para abandonarmos por completo a discussão acerca da materialidade ou imaterialidade da alma, e me faz condenar inteiramente a própria questão. Não possuímos ideia perfeita de nada senão de percepção. Uma substância é absolutamente diferente de uma substância. A inerência a alguma coisa é supostamente necessária para sustentar a existência de nossas percepções. Nada parece necessário para sustentar a existência de uma percepção. Portanto, não possuímos ideia alguma de inerência. Como seria possível, então, responder à questão se as percepções são inerentes a uma substância material ou imaterial, quando nem mesmo compreendemos o sentido da questão? (TNH, p. 266)
\end{abstract}

De tudo isso uma única conclusão se destaca: as percepções existem por si mesmas e em si mesmas. As percepções não são inerentes a nada, apenas a si mesmas, e isso em razão do princípio da exterioridade das percepções que Hume define cuidadosamente ao longo de todo o primeiro livro do Tratado, desde o início. Tal princípio instaura a imaginação como um solo nômade das ideias:

A mesma evidência nos acompanha em nosso segundo princípio, a liberdade que tem a imaginação de transpor e transformar suas ideias. Tal liberdade da fantasia não causará estranheza, porém, se considerarmos que todas as nossas ideias são copiadas de nossas impressões, e que não há duas impressões que sejam completamente inseparáveis - isso para não mencionarmos o fato de que se trata aqui de uma consequência evidente da divisão das ideias em simples e complexas. Sempre que a imaginação percebe uma diferença entre as ideias, ela pode facilmente produzir uma separação. (TNH, p. 34)

Princípio da exterioridade, da diferença ou da separabilidade. Eis o estatuto da imaginação em Hume. Evidencia-se assim a diferença entre as experiências: simples ou complexas, de sensação ou de reflexão. Os átomos da sensibilidade, dados pela experiência sensível, se experimentam entre sim na imaginação. Atomismo e associacionismo (Cf. DELEUZE, 2006, p. 212) ou, mais precisamente, impressões de sensação e de reflexão, respectivamente. Porém, conforme Hume já nos advertiu sobre o problema da inerência, as ideias não estão na imaginação, como se pertencessem a uma faculdade delas diferente. As ideias, as perfeitas ideias da imaginação, são a imaginação mesma. É o único entendimento possível, uma vez que as ideias não dependem de nada para sustentar as suas existências. Elas não são modos, não existem em outra coisa, não são imanentes a nada que seja delas diferente. Elas são imanentes tão somente a elas mesmas, existem por pura imanência. Hume é bastante claro sobre as consequências do princípio da exterioridade:

Mais ainda, tudo o que é diferente é distinguível, e tudo o que é distinguível é separável pela imaginação. Esse é outro princípio. (...) concluo que, uma vez que todas as nossas percepções são diferentes umas das outras e de tudo o mais no universo, também elas são distintas e

JUNIOR, Guilherme Müller. A metamorfose das ideias: os sentidos das impressões em Hume. Griot : Revista de 
separáveis, e podem ser consideradas existindo separadamente, e podem de fato existir separadamente, sem necessitar de mais nada para sustentar sua existência. (TNH, p. 266)

É preciso lembrar que as ideias, ao lado das impressões, são também percepções (Cf. TNH, p. 25). A imaginação, portanto, é a imanência pura das ideias, pois não pode ser concebida diferentemente delas. Essa imanência é um campo de experiência das ideias, é um plano unicamente constituído por elas mesmas, onde, como imagens, podem se atravessar, se prolongar uma na outra, variar e se refletir: impressão de reflexão. Foi Deleuze quem nos fez ver isso:

Hume afirma constantemente a identidade do espírito, da imaginação e da
ideia (...). Sem dúvida, Hume constantemente repete que a ideia está na
imaginação. Mas, aqui, a preposição não marca a inerência a um sujeito
qualquer; ao contrário, ela é metaforicamente empregada para excluir do
espírito como tal uma atividade distinta, a do movimento da ideia, para
assegurar, assim, a identidade do espírito e da ideia no espírito. A
preposição significa que a imaginação não é um fator, um agente, uma
determinação determinante; é um lugar, que é preciso localizar, isto é
fixar, é um determinável. Nada se faz pela imaginação, tudo se faz na
imaginação. Ela nem mesmo é uma faculdade de formar ideias: a produção
da ideia pela imaginação é tão-só uma reprodução da impressão na
imaginação. (DELEUZE, 2001, pp. 12-13)

Tudo isso se confirma em Hume, sobretudo em sua polêmica crítica à identidade pessoal (Cf. TNH, Livro 1, Parte 4, Seção 6). A mente, para ele, é tão somente um fluxo de percepções. Para ser coerente com sua posição sobre as percepções e sua não inerência, ele se viu obrigado a negar a existência de um "eu", isto é, de um sujeito de inerência. $O$ espírito, a mente do qual ele nos fala, é unicamente constituída pelas percepções. Não é uma substância, não tem identidade nem simplicidade. É ela tão somente um fluxo. Eis a famosa passagem do Tratado:

[...] arrisco-me a afirmar que os demais homens não são senão um feixe ou uma coleção de diferentes percepções, que se sucedem umas às outras com uma rapidez inconcebível, e estão em perpétuo fluxo e movimento. [...] Não há um só poder na alma que se mantenha inalteravelmente o mesmo, talvez sequer por um instante. A mente é uma espécie de teatro, onde diversas percepções fazem sucessivamente sua aparição; passam, repassam, esvaem-se, e se misturam em uma infinita variedade de posições e situações. Nela não existe, propriamente falando, nem simplicidade em um momento, nem identidade ao longo de momentos diferentes [...]. Mas a comparação com o teatro não nos deve enganar. A mente é constituída unicamente pelas percepções sucessivas; e não temos a menor noção do lugar em que essas cenas são representadas ou do material de que esse lugar é composto. (TNH, p. 285)

A mente não é diferente daquilo que nela se passa. $O$ que se pode ver, das sensações à reflexão, é um devir das percepções, a sua metamorfose. Só há um material que não cessa de se metamorfosear em uma experiência imanente. Trata-se de uma mudança do conceito de experiência, de um novo conceito, uma vez que esse se definirá como um processo de mutação, como uma metamorfose das ideias, na 
medida em que são elas que mudam de natureza, e por elas mesmas. Quando Hume nos fala em memória ou em imaginação, ele está conceituando as qualidades dessas metamorfoses, dessas diferenciações. Portanto, não há dois materiais distintos, tais como espírito e ideia. Só há um material ${ }^{10}$. Não se pode tomar a imaginação como uma atividade desse mesmo espírito, ou seja, como uma faculdade subjetiva à qual as ideias estariam submetidas. O empirismo de Hume é uma filosofia da experiência imanente. Imanente tão somente às percepções mesmas. Essa filosofia se debruça sobre as metamorfoses das percepções, das ideias e suas impressões, onde o "eu", inclusive, é apenas mais uma das suas metamorfoses.

10 Insistimos nesse entendimento, pois é aí que está a essência do pensamento empirista como procuramos mostrar. Falamos de um material para não falar em uma matéria, já que esta pressuporia a existência de uma forma. Não há nada mais inadequado para o empirismo, sobretudo esse desenvolvido por Hume, que o par matéria-forma. As ideias e as impressões não constituem uma matéria, assim como o espírito não se define por uma forma. Trata-se de apenas um único material que Hume nomeia de percepções. William James fala de um único "estofo" no mundo, tal qual um único material. A isso ele chama de "experiência pura", conceito instaurador do seu empirismo radical. (Cf. JAMES, pp. 2, 3, 21-47). James parece se aliar a esse empirismo de Hume, mesmo com todas as suas ressalvas que lhe conferem, sobretudo, a sua originalidade. 


\section{Referências bibliográficas:}

DELEUZE, Gilles. Empirismo e Subjetividade: ensaio sobre a natureza humana segundo Hume. Tradução de Luiz B. L. Orlandi. São Paulo: Editora 34, 2001. "Hume". In: A ilha deserta. Edição preparada por David Lapoujade. Organização da edição brasileira e revisão técnica Luiz B. Orlandi. São Paulo: Iluminuras, 2006.

HUME, David. Tratado da Natureza Humana. Tradução de Débora Danowski. 2. ed. rev. e ampliada. São Paulo: Editora UNESP, 2009.

Investigação sobre o Entendimento Humano. Tradução de José Oscar de Almeida Marques. São Paulo: Editora UNESP, 1999.

JAMES, William. Essays in radical empiricism. New York: Dover, 2003

Autor(a) para correspondência: Guilherme Müller Junior, Universidade Estadual do Norte do Paraná Av. Getúlio Vargas, 850, CEP, 86400-000, Jacarezinho - PR, Brasil. guilhermemuller@uenp.edu.br 